\title{
LUH AYU MANIK MAS SEBAGAI REPRESENTASI SUPERHERO PEREMPUAN BALI DALAM KOMIK
}

\section{LUH AYU MANIK MAS AS THE REPRESENTATION OF A BALINESE FEMALE SUPERHERO IN COMICS}

\author{
Hanifah P. Utami ${ }^{1}$, Aquarini Priyatna ${ }^{2}$, Tisna Prabasmoro ${ }^{3}$ \\ 1,2,3 Fakultas Ilmu Budaya Universitas Padjadjaran \\ Jl. Raya Bandung Sumedang KM.21, Hegarmanah, Kec. Jatinangor, Kabupaten Sumedang \\ e-mail: hanifahpujiutami08@gmail.com, aquarini@unpad.ac.id, tisna.prabasmoro@unpad.ac.id
}

Naskah Diterima: 9 Desember $2020 \quad$ Naskah Direvisi: 10 Maret $2021 \quad$ Naskah Disetujui :30 April 2021

DOI: $10.30959 /$ patanjala.v13i1.718

\begin{abstract}
Abstrak
Penelitian ini berangkat dari minimnya penggambaran karakter beridentitas Indonesia dan maraknya marjinalisasi karakter perempuan dalam komik superhero. Salah satu komik yang mewujudkan tradisi budaya dan kearifan lokal Indonesia adalah Luh Ayu Manik Mas, yang menampilkan kebudayaan Bali. Tulisan ini membahas bagaimana Luh Ayu Manik Mas merepresentasikan perempuan Bali yang terwujud dalam karakternya sebagai superhero. Penelitian ini dilakukan menggunakan metode analisis isi terhadap empat edisi komik Luh Ayu Manik Mas. Hasil penelitian menunjukkan bahwa Luh Ayu Manik Mas ditampilkan memanifestasi identitas lokal melalui sumber kekuatan, yang dinamakan dengan gelang Tri Datu, dan kepercayaannya pada Tri Hita Karana. Tri Datu diyakini sebagai sumber kekuatan hidup, sedangkan Tri Hita Karana diyakini sebagai prinsip hidup yang menjamin keharmonisan dalam setiap aspek kehidupan. Agama dan Budaya merupakan hal yang berbeda. Luh Ayu Manik Mas merepresentasikan superhero perempuan Bali yang dimuliakan oleh ajaran agama Hindu (sebagai agama dominan di Bali), ketika budaya Bali masih tunduk pada sistem patriarki.
\end{abstract}

Kata Kunci: Luh Ayu Manik Mas, komik superhero, identitas lokal, dan perempuan Bali.

\begin{abstract}
This research is motivated by two reasons, namely the lack of the presence of characters with the Indonesian identities, and the marginalization of female characters in superhero comics. One of the comics that is quite representative of presenting Indonesia's cultural traditions and local wisdom is Luh Ayu Manik Mas, which contains the Balinese culture. This paper discusses how Luh Ayu Manik Mas has represented the Balinese women through her character as a superhero. The research is carried out using the content analysis method on the four comic editions of Luh Ayu Manik Mas. The results of this study have shown that Luh Ayu Manik Mas was designed to appear to be a manifestation of local identity, such as a source of strength from the Tri Datu bracelet, and the belief in the Tri Hita Karana. Tri Datu is believed to be the source of life force and Tri Hita Karana as the principle of life that ensures harmony in every aspect of life. Religion and culture are two different things. Luh Ayu Manik Mas, represents the figure of a Balinese female superhero who is glorified by the teachings of Hinduism as the dominant religion in Bali, is in contrast to Balinese culture which is still subject to the patriarchal system.
\end{abstract}

Keywords: Luh Ayu Manik Mas, superhero comic, local identity, Balinese women 


\section{A. PENDAHULUAN}

Komik termasuk bagian dari budaya populer yang menjadi fenomena global dalam 80 tahun terakhir karena mengadopsi unsur sosial budaya, ekonomi, dan politik dalam setiap ceritanya. Salah satu genre komik yang populer di kalangan masyarakat adalah komik superhero. Komis jenis ini biasanya mengisahkan tentang perjalanan seorang superhero berkekuatan super dalam memperjuangkan nilai-nilai kebaikan untuk kepentingan masyarakat umum.

Komik superhero seringkali hanya membahas karakter-karakter superhero laki-laki saja, tidak banyak komik yang memberikan ruang pada perempuan untuk menjadi tokoh superhero (Palmer, 2004). Media secara berat sebelah telah menegaskan hierarki ideologi, sosial, politik dan ekonomi yang lebih berpihak kepada kaum laki-laki, dalam hal ini dengan menjadikan laki-laki sebagai skenario dasar tokoh superhero. Hal ini dapat dikaitkan dengan gagasan bahwa genre superhero seringkali disebut sebagai genre milik laki-laki, karena Schatz sebagaimana dikutip oleh Cawelti dalam Coogan (2018) menyebutkan bahwa genre ini identik dengan petualangan yang menampilkan individu atau kelompok pahlawan dalam mengatasi rintangan dan bahaya untuk menyelesaikan beberapa misi. Padahal, superhero perempuan juga telah menetapkan standar kekuatan mereka layaknya superhero laki-laki (Palmer, 2004). Selain itu, Salsabil (2019) juga menjelaskan dalam tulisannya bahwa perempuan selalu dikonotasikan sebagai pekerja domestik yang tidak dapat memberikan kontribusi secara aktif di luar ranah tersebut, sehingga peran superhero tidak sesuai dengan "pekerjaannya".

Meskipun demikian, kehadiran superhero perempuan dalam industri budaya populer bukanlah hal yang baru. Ajidarma sebagaimana dikutip oleh Kurniawan (2019) menjelaskan bahwa nilai-nilai ke-superhero-an dalam tokoh perempuan muncul dalam komik sebagai salah satu bentuk pemberontakan kultural. Salah satu bentuk pemberontakan tersebut dapat dilihat dari kekuatan maskulin yang dimiliki superhero perempuan dan penggambaran kostum feminin yang dikenakan (Salsabil, 2019). Perempuan juga seringkali menjadi subjek melalui gambarannya sebagai simbol seks, pencuri perhatian laki-laki, serakah, dan rapuh (Pratiwi, 2013).

Kajian mengenai superhero perempuan dalam komik Indonesia telah dilakukan oleh Salsabil (2019) terhadap komik superhero "Valentine". Kajian tersebut menunjukkan bahwa tubuh superhero Valentine dibentuk dan dihias menggunakan kostum yang seksi sebagai penegas sosok feminin, sedangkan otototot yang terdapat pada bagian tubuhnya menunjukkan sisi maskulinitas atau perempuan kuat. Kehadiran Valentine dan superhero perempuan lainnya dianggap mengganggu dikotomi gender karena menggambarkan sosok perempuan yang kuat secara fisik dengan karakter superior dan feminin di waktu yang bersamaan (Salsabil, 2019). Dalam kaitannya dengan penelitian Salsabil, kami mengemukakan dua hal yang sejalan dalam penelitian ini, yaitu (a) penggambaran kostum superhero perempuan dalam komik Indonesia dan (b) konsep kekuatan superhero perempuan dalam komik Indonesia. Dua hal tersebut akan kami kaitkan dengan kebudayaan lokal Bali.

Munculnya kebudayaan lokal dan penokohan perempuan dalam komik superhero di Indonesia dipengaruhi oleh bagaimana kondisi sosial, budaya, politik dan ekonomi suatu kelompok masyarakat. Ajidarma sebagaimana dikutip oleh Kurniawan (2019) dalam tulisannya menjelaskan bahwa komik bergenre superhero di Indonesia muncul dengan mengadopsi unsur-unsur mitologi lama, tradisi dan unsur-unsur budaya yang sudah lama ada di Indonesia. Kajian mengenai kebudayaan lokal dalam komik juga telah dibahas oleh Prabowo (2012) dalam penelitiannya yang berjudul "Representasi 
Identitas Lokal Sebagai Sebuah Subculture : Analisi Kritis pada Komik Garudayana". Ia menjelaskan bahwa komik menjadi sebuah ranah dari kontestasi kebudayaan, komik Garudayana yang menjadi objek penelitiannya mengkolaborasi konten lokal pewayangan dan visualisasi manga khas Jepang. Alur cerita komik, setting tempat dan penokohan bersandar pada hal-hal yang sarat akan kebudayaan Indonesia. Hal ini menunjukkan bahwa komik lokal Garudayana hadir sebagai sebuah kemasan bauran antara budaya populer dan identitas lokal, sekaligus menunjukkan bahwa eksistensi komik lokal bukan merupakan budaya tandingan (counter culture) terhadap komik impor. Ridho (2014) dalam tulisannya juga menjelaskan bahwa Garudayana memiliki elemen identitas hibrida. Identitas tersebut ditampilkan melalui penokohan, konsep cerita, penggambaran visual, tempat, dan tokoh binatang-binatang khas Nusantara yang memperkuat kesan lokalitas Indonesia. Sementara itu, elemen-elemennya ditampilkan melalui manga sebagai gaya gambar dan identitas kultural Jepang yang memiliki elemen identitas hibrida berupa kode visual dan kode linguistik.

Salah satu komik yang mengangkat unsur-unsur kebudayaan lokal dengan tokoh superhero perempuan adalah Luh Ayu Manik Mas yang diciptakan oleh Tim Basabali Wiki. Tim Basabali Wiki menamai proyek komik superhero ini dengan proyek Luh Ayu Manik Mas. Komik Luh Ayu Manik Mas menggunakan kebudayaan lokal secara spesifik dalam penceritaannya, yaitu Bali. Berdasarkan data dari siaran langsung instagram oleh akun@kinokuniya bersama Tim Basabali Wiki, Ni Nyoman Ayu Suciartini selaku penulis komik Luh Ayu Manik Mas edisi keempat menyebutkan bahwa masih sedikitnya tokoh superhero perempuan Bali yang dituliskan dalam teks komik. Selain itu, visi misi Tim Basabali Wiki dalam proyek ini adalah mengupayakan pemberdayaan kaum perempuan. Dengan demikian, kajian mengenai komik lokal ini menjadi penting karena jumlah tokoh superhero perempuan dan superhero Bali yang masih terbatas.

Sebagai karya teks yang merupakan representasi dari nilai-nilai, mitos, ideologi dan gagasan budaya, Luh Ayu Manik Mas membantu para pembacanya dalam mengenal kebudayaan masyarakat Bali. Komik ini menggambarkan kehidupan masyarakat Bali pada umumnya, dilengkapi dengan beberapa bagian mengenai tradisi dan kepercayaan yang menjadi pedoman hidup orang Bali dalam bermasyarakat. Beberapa kegiatan yang dilakukan tokoh-tokoh dalam komik ini merupakan seperangkat mekanisme kontrol yang disebut sebagai kebudayaan. Kebudayaan dalam hal ini juga meliputi pembelajaran tentang penerimaan tradisi, sifat bawaan, bahasa, agama, keturunan dari suatu kehidupan masyarakat. Identitas Indonesia dan perempuan yang dimasukkan oleh Tim Basabali Wiki dalam komik ini menjadi kekuatan; unsur-unsur yang merujuk pada identitas budaya Bali diciptakan dan disesuaikan dengan konsepkonsep yang secara historis telah menjadi stereotipe yang baku.

Hingga Juni 2020, Tim Basabali Wiki sudah meluncurkan empat edisi komik yang hadir sejak Mei 2019 (BASAbali, 2020). Pada tahun 2019, Tim Basabali Wiki sebagai penerbit komik ini telah menerima dua penghargaan dari Asia Foundation. Penghargaan pertama diberikan atas terjemahan sejumlah buku cerita dari bahasa Indonesia ke dalam bahasa Bali, sedangkan penghargaan kedua diberikan atas penciptaan karakter superhero perempuan Bali (Prawireng Putri Bali) beserta penulisan empat kisah petualangannya. Komik Luh Ayu Manik Mas sebagai salah satu komik superhero perempuan memberikan pandangan baru dalam industri komik Indonesia setelah tokoh Sri Asih, Puteri Bintang dan lainnya.

Luh Ayu Manik merupakan siswi kelas delapan asli Bali yang menjelma menjadi superhero perempuan Luh Ayu Manik Mas dengan balutan kostum khas 
perempuan Bali. Seperti superhero pada umumnya, Luh Ayu Manik Mas memiliki alter-ego sehingga dirinya mempunyai dua identitas (manusia biasa dan manusia super). Selanjutnya kami menyebut nama "Luh $A y u$ " untuk identitas dirinya sebagai manusia biasa dan "Manik Mas" untuk identitas dirinya sebagai manusia super atau superhero. Secara umum, Luh Ayu digambarkan sebagaimana anak gadis remaja pada umumnya, yang melakukan kegiatan bersekolah, bermain bersama teman-teman, membantu orang tua, membaca buku, menonton televisi, melakukan ibadah, dan mengikuti kegiatan masyarakat di lingkungan tempat tinggalnya. Terdapat beberapa hal terkait praktik kebudayaan Bali yang disisipkan dalam cerita komik, hal tersebut menunjukkan ciri khasnya secara jelas sebagai orang Bali. Praktik kebudayaan tersebut tergambar melalui kekuatan super, pakaian Manik Mas, bahasa yang digunakan oleh para tokoh dalam komik, bahasa yang disajikan dalam karya teks, dan jenis kegiatan yang diikuti oleh $L u h$ Ayu dan teman-temannya.

Manik Mas merupakan superhero perempuan Bali yang turut melestarikan lingkungan alam dan budaya Indonesia menggunakan kekuatan supernya. Tidak dituliskan secara spesifik kekuatan yang dimiliki Manik Mas, namun kekuatan yang dimilikinya sangat beragam dalam setiap edisi komik. Pada edisi pertama dan kedua, kekuatannya seperti sebuah deru angin, pukulan tangan, dan tendangan kaki. Sedangkan pada edisi ketiga dan keempat, kekuatannya berupa deru air kuat yang berasal dari sebuah tongkat kecil dan cambuk tiga warna. Sebuah tongkat mulai terlihat ketika Luh Ayu melakukan transformasi menjadi Manik Mas dengan memanfaatkan gelang tiga warna di tangannya. Jadi, proses transformasinya melibatkan empat hal penting, yaitu gelang tiga warna, tongkat kecil, dan wujud kekuatannya (angin, air atau cambuk tiga warna). Deru angin, air, dan cambuk tiga warna tersebut digunakan oleh Manik Mas untuk melawan monster-monster yang dihadirkan dalam komik. Monster-monster tersebut diceritakan sebagai monster yang mengganggu lingkungan dan masyarakat Bali. Manik Mas di sini berperan sebagai tokoh superhero perempuan yang menjaga tanah Bali dari kejahatan-kejahatan dalam aspek lingkungan.

Mengingat tujuan penelitian ini adalah untuk menggambarkan Luh Ayu Manik Mas sebagai representasi dari superhero perempuan Bali, untuk itu kami membahas isu ini dalam perspektif identitas kultural dan gender. Seperti yang dikemukakan Hall (1997) bahwa representasi mampu menghubungkan konsep-konsep dalam benak individu untuk memproduksi makna yang bekerja dengan melibatkan penggunaan bahasa (language), tanda, dan gambar. Representasi kemudian dikaitkan dengan konsep Superhero (Coogan, 2018), dan Prinsip Hidup Masyarakat Bali (Punia \& Nugroho, 2020). Selain itu, kami juga melengkapi bahasan tersebut dengan tulisan Robb (2014) mengenai karakteristik superhero, sistem penamaan Bali (Temaja, 2017), Perempuan dalam Agama Hindu (Rahmawati, 2016), dan Filosofi Hidup Tri Datu bagi masyarakat Bali (Merthawan, 2017).

Komik superhero menjadi salah satu hal yang penting untuk dibahas karena terbatasnya penelitian mengenai komik superhero di Indonesia. Menurut Ajidarma sebagaimana dikutip oleh Kurniawan (2019) bahwa hal ini dapat dilihat dari salah satu fakta bahwa sejarah komik Indonesia yang sudah terentang selama 80 tahun lebih, namun hanya sedikit karya ilmiah yang mengkaji komik Indonesia. Minimnya perkembangan karakter superhero dengan identitas perempuan dalam komik lokal menjadi urgensi dalam penelitian ini.

\section{B. METODE PENELITIAN}

Penelitian tekstual ini mengkaji karakter Luh Ayu Manik Mas yang merepresentasikan perempuan Bali dalam komik Luh Ауи Manik Mas. Objek 
penelitian adalah empat edisi komik Luh Ayu Manik Mas yang terbit sejak Mei 2019 hingga Juni 2020. Keempat edisi komik yang dipilih untuk menjadi objek penelitian adalah Tresna Ring Alas, Ngae Perpustakaan Keliling, Pahlawan Lingkungan, dan Nglawan Luu Palastik. Metode penelitian yang dilakukan adalah analisis isi, dengan melakukan pembahasan mendalam terhadap isi suatu informasi tertulis atau tercetak dalam media massa. Analisis yang dipelopori oleh Lasswell ini dijelaskan sebagai analisis yang menafsirkan atau menginterpretasikan semua petanda yang terdapat dalam teks media (Sobur, 2001). Dengan demikian, kami tidak hanya menganalisis gambar dalam komik yang secara mendalam, melainkan seluruh bagian yang tercetak dalam komik menjadi objek analisis penelitian ini.

Kami menggunakan metode penelitian ini dengan mengambil data berupa gambar, rincian detail mengenai sebuah situasi dan uraian naratif tentang situasi sosial yang tersirat dalam narasi komik. Kami melakukan pengamatan setiap panel dan teks dalam komik. Proses ini dilakukan secara interaktif dan berlangsung secara terus menerus sampai tuntas hingga datanya jenuh. Dengan demikian, hasil analisis dari empat edisi komik ini mampu menampilkan bagaimana Luh Ayu Manik Mas merepresentasikan superhero perempuan Bali dalam komik.

\section{HASIL DAN BAHASAN}

Salah satu genre komik yang populer di kalangan masyarakat adalah komik superhero. Karakter dalam komik layak disebut sebagai "superhero" jika memenuhi beberapa kriteria; seorang superhero adalah "karakter heroik" dengan misi, kekuatan super dan identitas khusus yang dapat dikenali (Coogan, 2018). Karakteristik superhero banyak ditetapkan dalam komik aksi terbitan pertama komik DC; Superman yaitu memiliki misi altruistik (hanya mempedulikan orang lain), memiliki kekuatan super, kelemahan yang fatal, berdedikasi kuat tanpa pamrih, serta memiliki konflik dengan alter-egonya (Robb, 2014). Tokoh superhero perempuan Indonesia pertama adalah Sri Asih karya Raden Ahmad Kosasih yang muncul pada tahun 1953. Selain Sri Asih, lahir pula tokoh-tokoh superhero perempuan Indonesia lainnya seperti Siti Gahara (Hasian \& Mardika, 2017), Puteri Bintang karya John Lo (Kurniawan, 2019), dan Nina Gadis Rimba.

Selain tokoh-tokoh superhero perempuan legendaris tersebut, komik Indonesia lainnya yang menampilkan tokoh superhero perempuan dengan kebudayaan lokal adalah Luh Ayu Manik Mas. Komik Luh Ayu Manik Mas pertama kali diterbitkan oleh Tim Basabali Wiki pada tahun 2019. Sebelum analisis dilakukan pada keempat edisi komik, terlebih dahulu dipaparkan mengenai gambaran umum budaya masyarakat dan lingkungan alam Bali yang tergambar dalam komik. Melalui gambaran tersebut, proses analisis mengenai Luh Ayu Manik Mas sebagai representasi dari superhero perempuan Bali dapat dikaitkan dengan prinsip hidup yang diaplikasikan dalam kehidupan sehari-hari oleh masyarakat Bali. Hasil analisis dari keempat edisi komik Luh Ayu Manik Mas menghasilkan uraian naratif dengan sub bab: Lingkungan Alam Bali dalam Gambaran Komik dan Luh Ayu Manik Mas sebagai Representasi Superhero Perempuan Bali.

\section{Lingkungan Alam Bali dalam Gambaran Komik}

Bali sebagai bagian dari negara Indonesia dikenal dengan sejarah dan budaya warisan leluhur yang masih kental. Tradisi agama Hindu sebagai agama mayoritas di Bali menjadi "napas" dari budaya Bali itu sendiri, karena secara historis, kultur yang dibangun di Bali lebih dominan berada dalam pengaruh Agama Hindu. Mayoritas masyarakat Bali bertumpu pada angka tiga dalam berbagai hal karena identik dengan konsep-konsep teologi Hindu Bali yang selalu menyisipkan unsur angka tiga atau 
tri, seperti Tri Datu, Tri Hita Karana, Tri Murti, Tri Kaya Parisudha, dan sebagainya (Punia \& Nugroho, 2020).

Seperti halnya agama Hindu memiliki tiga kerangka dasar dalam kehidupan, yaitu tatwa (filsafat keagamaan), susila (moral keagamaan), dan upacara (upacara keagamaan). Masyarakat Hindu Bali memegang kepercayaan "Panca Crada" yang dimaknai dengan kepercayaan pada satu Tuhan dalam bentuk konsepsi Tri Murti. Tri Murti berwujud dalam tiga Dewa yaitu Brahmana (yang menciptakan), Wisnu (yang melindungi dan memelihara), dan Syiwa (yang melebur segala yang ada).

Salah satu filosofi hidup masyarakat Bali yang terkenal adalah konsep Tri Hita Karana. Konsep ini memiliki makna tiga penyebab kesejahteraan, di mana Tri bermakna tiga, Hita bermakna sejahtera, dan Karana berarti penyebab. Kehidupan masyarakat Bali berlandaskan pada konsep Tri Hita Karana yang dijiwai oleh ajaran agama Hindu. Hal ini menekankan pentingnya falsafah Tri Hita Karana dalam penerapannya di kehidupan sehari-hari, bahwa keharmonisan hubungan manusia dengan Tuhan (parhyangan), manusia sesama manusia (pawongan), dan manusia dengan lingkungan alam (palemahan) sangat penting untuk mencapai kesejahteraan. Keharmonisan yang dimaksud dalam tujuan ini merupakan aplikasi hal-hal baik dan suci dalam pikiran, perkataan, dan perbuatan.

Konsep filosofis hidup lainnya, Tri Datu diartikan oleh Merthawan (2017) sebagai susunan benang dengan nilai filosofis yang diyakini oleh umat Hindu memiliki kekuatan. Benang Tri Datu digunakan dalam bentuk gelang oleh masyarakat Bali sebagai pelengkap upacara keagamaan tertentu. Ketiga warna dalam benang Tri Datu melambangkan konsep Ajaran Tri Murti sebagai lambang kesucian, warna merah melambangkan Dewa Brahma (pencipta), warna hitam melambangkan Dewa Wisnu (pemelihara) dan warna putih melambangkan Dewa
Siwa (pelebur) sebagai manifestasi Ida Sang Hyang Widhi Wasa (sebutan bagi Tuhan yang Maha Esa dalam agama Hindu Dharma pada masyarakat Bali). Berkaitan dengan tiga dewa dalam ajaran agama Hindu di Bali, masing-masing dewa memiliki simbol. Air sebagai simbol dari Dewa Wisnu, api sebagai simbol dari Dewa Brahma dan angin sebagai simbol Dewa Siwa.

Kami mengaitkan prinsip hidup Tri Hita Karana dan Benang Tri Datu dalam analisis ini. Masyarakat Hindu Bali menjadikan kedua prinsip ini sebagai prinsip hidup untuk menciptakan keharmonisan dan kesejahteraan dalam kehidupan. Salah satu hubungan yang ditekankan dalam konsep Tri Hita Karana adalah hubungan manusia dengan lingkungan. Dalam konsep Tri Hita Karana, tanah Bali merupakan wujud dari palemahan atau lingkungan alam yang dijaga. Dalam komik ini, Manik Mas digambarkan sebagai sosok superhero perempuan yang menggunakan kekuatannya untuk melestarikan lingkungan alam dan budaya Indonesia. Hal tersebut digambarkan dalam setiap edisi komik. Ia berupaya untuk menjaga kelestarian pohon di hutan (komik edisi pertama), memanfaatkan buku-buku bekas dengan membuka perpustakaan keliling (komik edisi kedua), dan membersihkan sampah-sampah di sungai dan pantai (edisi ketiga dan keempat). Manik Mas berupaya untuk membangun hubungan yang harmonis antara manusia dan lingkungan melalui perbuatannya sebagai superhero perempuan. Konsep Tri Hita Karana ini menekankan bahwa masyarakat Hindu Bali memandang alam sebagai suatu sistem yang dikendalikan oleh nilai keseimbangan, dan diwujudkan dalam bentuk perilaku.

Masyarakat Hindu percaya bahwa alam semesta diciptakan oleh Tuhan dan dengan Tuhan pula alam semesta ini akan dikembalikan. Manusialah yang menjadi titik sentral dalam pelestarian kesucian semesta alam, jika kesucian tersebut 
terbangun dengan sempurna, maka alam semesta pun akan menjadi sempurna. Luh Ayu dan Manik Mas melakukan penjagaan alam semesta secara turun temurun sebagai wujud rasa syukur terhadap Tuhannya, dengan harapan bahwa alam semesta akan mampu mengalami proses kelahiran, kehidupan dan kematian yang berulangulang. Untuk itulah hubungan harmonis yang dilakukannya bertujuan untuk mewujudkan kesejahteraan masyarakat, khususnya memberi pelajaran bagi masyarakat Bali yang melanggar normanorma lingkungan di daerah tersebut dan memberikan kedamaian bagi masyarakat lainnya.

Pemeliharaan lingkungan tergambar berulang kali dalam cerita komik superhero Luh Ayu Manik Mas. Panel komik lain yang juga menceritakan hubungan manusia dengan lingkungan adalah penebangan pohon ilegal pada komik edisi pertama. Luh Ayu bersama teman-temannya mencari tahu pelaku penebangan pohon di hutan, dan berupaya untuk menanam kembali pohon untuk menjaga kelestarian pohon. Dalam mitologi Hindu Bali, terdapat istilah mengenai pelestarian pohon yaitu kayu larangan (kayu yang dilindungi kerajaan) yang dipercaya oleh masyarakat Hindu sebagai tradisi yang harus ditaati. Masyarakat Bali di kawasan tri danu percaya bahwa jika menebang pohon secara ilegal tanpa memohon kepada pihak desa adat atau melanggar tradisi tersebut akan mendapat kutukan dari para leluhur (Candrawan, 2015). Hal ini menjadi salah satu kepercayaan yang berkaitan dengan dua unsur konsep Tri Hita Karana: lingkungan dan Tuhan. Diceritakan pula dalam komik bahwa Manik Mas melapor kepada polisi hutan yang mengerti akan peraturan pemerintah mengenai penebangan pohon ilegal. Tindakan Manik Mas menunjukkan bahwa adanya hukum formal, baik berupa Perda ataupun Undang-Undang yang berperan penting terhadap pelaksanaan kearifan lokal yang berkaitan dengan pelestarian lingkungan di
Bali sesuai dengan prinsip hidup Tri Hita Karana. Dalam upaya mencapai keharmonisan manusia dengan lingkungan, Luh Ayu dan Manik Mas mewujudkannya melalui tindakan.

Ketika Luh Ayu dan teman-temannya bermain di pantai dalam cerita komik edisi pertama, ombak besar dan angin kencang pun datang secara tiba-tiba. Luh Ayu mengingatkan teman-temannya untuk menjauhi pantai dan menepi ke perumahan warga untuk mencari perlindungan. Salah satu teman Luh $A y u$, Luh Putu Suastini mulai khawatir karena ia teringat bahwa ayahnya masih berada di sawah ketika badai datang. Luh Ayu dengan rasa empatinya segera menenangkan Luh Putu Suastini dengan meyakinkan bahwa ayahnya tidak akan celaka dan akan segera mencari perlindungan di sekitar sawah. Luh Ayu digambarkan memberikan perlindungan dan kekuatan mental kepada temannya dengan mengucapkan ucapan baik yang menenangkannya. Hubungan antara manusia dengan manusia tergambar melalui perlindungan yang diberikan $\mathrm{Luh}$ Ауи untuk teman-temannya. Ia berusaha untuk membangun hubungan harmonis antara dirinya dengan teman-temannya melalui perkataan dan perbuatan baik.

Pada komik edisi kedua, Luh Ayu juga berusaha untuk membangun hubungan harmonis antar manusia. Ketika pulang sekolah, ia melihat kejahatan terjadi pada seorang turis laki-laki. Sebuah gawai, dompet, laptop, dan dokumen penting dirampas oleh dua orang pengendara motor. Melihat tindakan tersebut, Luh Ayu dengan sigap turun dari motor dan bertransformasi menjadi superhero Manik Mas untuk mengejar kedua perampas. Setelah berhasil melawan perampas, Manik Mas segera mengembalikan barang-barang rampasan ke turis selaku korban. Turis tersebut berterimakasih kepada Manik Mas dan memberinya buku sebagai imbalan atas pertolongannya. Meskipun tidak saling kenal, Luh Аyu melakukan pertolongan kepada turis sebagai bentuk upayanya dalam membangun hubungan 
harmonis antar manusia. Hubungan harmonis tersebut berhasil diciptakan antara Luh $A y u$ dan turis laki-laki yang ditampilkan melalui ucapan terimakasih dan pemberian buku sebagai imbalan oleh turis. Bentuk keharmonisan antar manusia juga ditampilkan berulang kali oleh Luh Ayu dan Manik Mas kepada beberapa tokoh dalam komik pada edisi ketiga dan keempat. Keharmonisan tersebut tergambar melalui bantuan yang diberikan Luh Ayu kepada neneknya untuk membuat sesajen sebelum melakukan ritual banyu pinaruh di pantai.
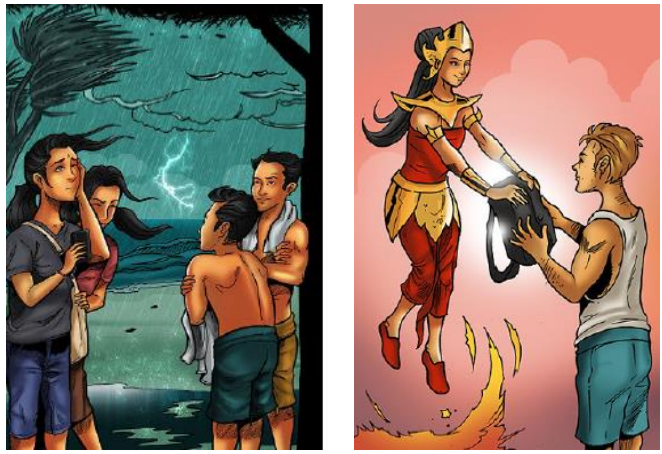

Gambar 1. Hubungan Harmonis antara Luh Ayu, Manik Mas, dan Beberapa Tokoh dalam Komik.

Sumber: https://dictionary.basabali.org/

Keharmonisan hubungan manusia dengan Tuhan (parhyangan) dalam konsep Tri Hita Karana tergambar dalam kedua edisi terakhir komik ini. Pada komik edisi ketiga, Luh Аyи bersama masyarakat sekitar melaksanakan ritual pangrupukan yang termasuk bagian dari susunan perayaan hari raya Nyepi. Ritual pangrupukan ini diselenggarakan satu hari sebelum hari raya Nyepi, tepatnya pada hari mati (tilem) sasih kasanga dalam kalender agama Hindu. Masyarakat Hindu Bali percaya bahwa pelaksanaan upacara ini mampu menjaga keseimbangan alam semesta dan manusia dari gangguan bhuta kala. Bhuta kala merupakan makhluk halus ciptaan Tuhan yang dapat mengganggu alam semesta (bhuana agung) dan manusia (bhuana alit) (Suwena, 2017). Bhuta kala dipandang lebih rendah derajatnya daripada manusia oleh masyarakat Bali. Luh Аyи bersama teman dan masyarakat desa lainnya merayakan upacara ini dengan menonton pertunjukan ogoh-ogoh yang diiringi bunyi-bunyian dari alat musik tradisional Bali. Secara simbolis, ogoh-ogoh yang ditampilkan dalam komik pada upacara ini merupakan manifestasi dari bhuta kala yang ditampilkan dengan wujud besar seperti raksasa dengan mata melotot dan mulut terbuka.
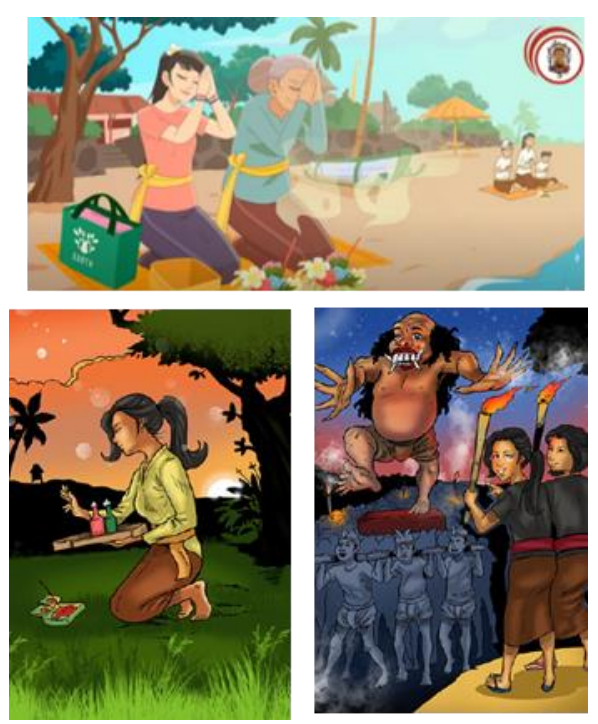

Gambar 2. Luh Ayu Melakukan Ritual Keagamaan Bersama Kerabat

Sumber: https://dictionary.basabali.org/

Ibu Luh Ayu turut berpartisipasi dalam pelaksanaan upacara pangrupukan, diceritakan dalam komik berbelanja ke pasar untuk membeli bahan guna membuat caru. Caru dijelaskan oleh Suwena (2017) sebagai kurban berupa nasi (juga dapat menggunakan binatang) yang dimaksudkan sebagai seserahan (sesajen) yang disajikan dan dihaturkan kepada bhuta kala dalam upacara pangrupukan. Ritual keagamaan pangrupukan, kepercayaan terhadap bhuta kala, dan seserahan yang disajikan dalam komik ini merupakan bentuk upaya yang dilakukan Luh Ayu dan tokoh lainnya untuk mencapai keharmonisan hubungan manusia dengan 
Tuhannya. Luh Ayu sebagai perempuan Bali memercayai sesuatu yang tidak terlihat dan menjalankan ragam ritual keagamaan sebagai bentuk besar kepercayaannya terhadap Tuhannya.

Sedangkan pada komik edisi keempat, Luh Ayu melakukan ritual keagamaan yang disebut dengan Banyu Pinaruh bersama neneknya. Banyu Pinaruh merupakan bagian dari susunan pelaksanaan perayaan hari raya Siwaratri. Ritual Banyu Pinaruh dijelaskan oleh Suarnada and Ritawati (2017) sebagai ritual yang dilakukan untuk memohon sumber air pengetahuan untuk membersihkan kotoran atau kegelapan pikiran (awidya) yang melekat dalam tubuh manusia. Ritual ini dilakukan dengan mencari sumber air sebagai media peluruhan kotoran, biasanya masyarakat Bali akan pergi ke pantai untuk melakukan ritual ini pada pagi hari setelah perayaan hari raya Siwaratri. Luh Ayu dan neneknya pergi ke pantai yang merupakan salah satu sumber air di daerahnya dengan membawa sesajen guna membersihkan dirinya dari hal-hal kotor yang melekat. Air digunakan sebagai media peluruhan kotoran dalam tubuh manusia dalam ajaran agama Hindu karena air diyakini masyarakat Bali sebagai hal yang bernilai keramat atau suci. Kegiatan keagamaan yang dilakukan Luh Ауи bersama neneknya merupakan bentuk keharmonisan yang ia upayakan untuk mendapatkan kesejahteraan antara Tuhan dan manusia. Keharmonisan yang dimaksud dalam tujuan ini merupakan aplikasi hal-hal baik dan suci dalam pikiran, perkataan, dan perbuatan.

Manik Mas sebagai superhero perempuan Bali direpresentasikan dalam komik Luh Ayu Manik Mas sebagai perempuan Bali yang menjunjung tinggi konsep Tri Hita Karana sebagai pedoman hidupnya. Luh Ayu dan Manik Mas melakukan kontrol diri atas pikiran, perkataan dan perbuatan atas dasar prinsip hidup Tri Hita Karana. Prinsip hidup masyarakat Bali selanjutnya, Tri Datu tergambar dalam penggunaan aksesoris gelang Tri Datu oleh tokoh Luh Ayu dan
Manik Mas, yang selanjutnya dijelaskan pada bab Luh Ayu Manik Mas sebagai representasi perempuan Bali.

Jika melihat tokoh Luh Ayu dan Manik Mas, nama yang ditampilkan adalah nama khas perempuan Bali yaitu dengan menggunakan "Luh" dan "Ayu". Temaja (2017) dalam penelitiannya menjelaskan bahwa sistem penamaan orang Bali didasarkan pada tiga aspek, yaitu jenis kelamin, urutan kelahiran, dan kasta. Pengunaan nama " $L u h$ " dan "Ayu" menandai nama seorang perempuan, yang mana penamaan ini dipilih berdasarkan pemisahan jenis kelamin. Sedangkan dari sistem kastanya, nama "Ayu" digunakan oleh beberapa kasta pada masyarakat Bali sebagai penanda jenis kelamin perempuan.

Sistem penamaan Bali yang digunakan dalam komik ini merupakan bentuk petanda adanya kearifan lokal dalam komik yang menempatkan perempuan sebagai sosok yang sakti. Sistem ini menjadi suatu keunikan tertentu bagaimana budaya Bali memengaruhi aspek lingual penamaan. Selain nama $L u h$ Ayu dan Manik Mas, nama temantemannya juga yang termasuk dalam sistem penamaan Bali seperti Luh Putu Suastini, I Madé Anjasmara, Ketut Suprabawa, Ayu Kinandari, I Wayan, Pak Budiadnyana, dan Putu Nita. Komik ini menampilkan bagaimana sistem kebudayaan Bali dengan sentuhansentuhan modern berlaku di masyarakat, dan menjadi ciri khas komik Luh Ayu Manik Mas.

Tim Basabali Wiki menyajikan komik Luh Ayu Manik Mas dalam tiga bahasa, yaitu bahasa Bali sebagai bahasa utama, bahasa Indonesia, dan bahasa Inggris. Tim Basabali Wiki menggunakan bahasa Bali sebagai bahasa utama dalam komik ini dengan tujuan untuk melestarikan bahasa ibu bagi masyarakat Bali. Namun, kami melihat sesuatu yang tersirat dari keputusan pemilihan ketiga bahasa tersebut. Selain sebagai bentuk pemeliharaan bahasa lokal, pemilihan ketiga bahasa sebagai media penyampaian 
komik ini juga merupakan terapan dari prinsip hidup Tri dalam masyarakat Bali. Jumlah bahasa yang dipilih adalah tiga, sesuai dengan keyakinan masyarakat Bali yang bertumpu pada angka tiga dalam berbagai hal karena identik dengan konsep-konsep teologi Hindu Bali. Bahasa Inggris dipilih karena merupakan bahasa internasional, bahasa Indonesia dipilih sebagai bahasa nasional, dan bahasa Bali dipilih sebagai bahasa lokal.

\section{Luh Ayu Manik Mas sebagai Representasi Superhero Perempuan Bali}

Tokoh superhero perempuan Manik Mas merupakan perempuan beridentitas Bali. Perempuan dalam ajaran agama Hindu, sebagai ajaran yang diyakini kebenarannya secara dominan oleh masyarakat Bali sangat dimuliakan, bahkan perempuan dipuja sebagai dewi, dianggap "sakti" (perwujudan dari aspek perempuan Tuhan) dan memiliki kekuatan mistis bagi laki-laki (Rahmawati, 2016). Kata "sakti" di sini juga melambangkan keaktifan, energi, asas dinamis dan kekuatan feminin yang dimiliki perempuan. Jika superhero biasanya ditampilkan dalam wujud lakilaki, pemilihan karakter perempuan untuk tokoh superhero menjadi sebuah kekuatan. Tokoh superhero Luh Ayu dan Manik Mas dalam komik merepresentasikan sosok perempuan dalam ajaran agama Hindu yang memiliki kekuatan, energi, dan kekuatan feminin dalam dirinya.

Masing-masing dari wujud Tri Murti yang merupakan perwujudan Tuhan dalam agama Hindu dilukiskan berpasangan dengan dewi. Dewi-dewi tersebut adalah Dewi Saraswati (Hyangning Pangaweruh/Dewi Ilmu Pengetahuan), Dewi Sri dan Dewi Laksmi (melambangkan kemakmuran dan kesejahteraan), serta Dewi Uma dan Dewi Durga yang merupakan lambang dari sifat pengasih, penyayang serta dapat melebur kejahatan (Kiriana, 2017). Para dewi yang sudah dianggap sebagai Tuhan perempuan dalam agama Hindu merupakan manifestasi dari kekuatan perempuan. Kekuatan tersebut ditampilkan melalui aspek pengetahuan dan beberapa sifat feminin. Luh Аyи sebagai superhero Bali memiliki kekuatan dalam bidang pengetahuan yang terlihat dari statusnya sebagai pelajar SMP. Hal ini menandakan bahwa ia memiliki kesempatan untuk menempuh pendidikan. Selain itu, teks di bawah ini juga menunjukkan kekuatannya dalam pengetahuan:

"Sujatine di tasne ane mawarna selem ento misi majalah remaja, misi masih buku-buku pameran lukisan ane tekaina dugas $i$ puan ajak Memenne" (Dwijayanthi, 2019).

Teks tersebut diartikan "sebenarnya, di dalam tasnya yang berwarna hitam terdapat beberapa majalah remaja, bukubuku pameran lukisan yang pernah didatanginya bersama ibunya". Kepemilikan majalah dan buku serta kebiasannya yang selalu membawa buku di tasnya merupakan bentuk penanda bahwa ia adalah murid yang rajin membaca dan berpengetahuan luas. Selain pengetahuan, Luh Ayu dan Manik Mas juga memiliki sifat-sifat feminin seperti halnya kekuatan para dewi, yaitu rasa peduli, kasih sayang, empati, dan sifat kepemimpinannya. Luh Ayu dan Manik Mas dalam komik ini digambarkan sebagai sosok superhero perempuan yang memanifestasi sifat-sifat para dewi sebagai dewi yang diagungkan dalam ajaran agama Hindu.

Perempuan dalam ajaran agama Hindu memegang peranan sangat penting dalam kehidupan bermasyarakat seperti kegiatan keagamaan, pendidikan, maupun ekonomi (triple roles). Dalam ritual keagamaan, perempuan bertugas membuat persembahan upacara, perempuan menjadi kunci dalam kegiatan panen, perempuan dituntut untuk mempersiapkan semua sesajian serta hal-hal yang berhubungan dengan persiapan kegiatan adat atau keagamaan. Dapat dikatakan bahwa tanpa perempuan, upacara adat atau keagamaan 
di Bali tidak akan berjalan dengan baik. Hal ini tergambar dalam komik melalui peran Ibu Luh Ayu yang turut berpartisipasi dalam pelaksanaan upacara pangrupukan pada komik edisi ketiga. Selain itu, Luh Ayu bersama teman-teman perempuan juga turut menyemarakkan kegiatan keagamaan tersebut. Peran Luh Ayu dalam komik ini adalah sebagai perempuan yang aktif dalam kehidupan bermasyarakat. Dalam bidang ekonomi, kami berasumsi bahwa ibu Luh Ayu merupakan perempuan yang bertanggung jawab atas kebutuhan ekonomi keluarga secara keseluruhan. Sejak komik terbitan pertama, tidak terlihat sekalipun sosok ayah sebagai kepala keluarga dalam keluarga Luh Ayu. Hal ini menguatkan asumsi kami mengenai beban ekonomi yang ditanggung ibu Luh Ayu.

Dalam komik ini, Manik Mas menggunakan kekuatannya untuk menolong korban-korban kejahatan. Hal yang menjadi poin utama adalah beberapa korban kejahatan atau seseorang yang dilindungi Manik Mas menggunakan kekuatan fisiknya adalah laki-laki. Melalui analisis yang sudah dilakukan, tokoh lakilaki yang hadir dalam keempat edisi komik Luh Ayu Manik Mas adalah I Wayan, I Made, gambaran tokoh pejabat pemerintah yang korupsi, penebang pohon ilegal, polisi, turis asing, dan pembuang sampah. Seluruh tokoh laki-laki yang ada di komik ini digambarkan sebagai tokoh yang penakut, membutuhkan perlindungan, pelanggar aturan, dan tidak memiliki sopan santun dalam bersosialisasi dengan manusia maupun alam sekitar. Hal ini menunjukkan bahwa Manik Mas ditampilkan sebagai sosok perempuan yang memperkuat peran perempuan dalam kehidupan masyarakat Bali yang masih tunduk pada sistem patriarki.

Tokoh superhero perempuan Luh Ayu dan Manik Mas yang dihadirkan dalam komik merupakan manifestasi dari ajaran agama Hindu yang memuliakan perempuan. Luh Ayu dan Manik Mas sebagai perempuan Bali justru menampilkan kekuatan perempuan yang bertolak belakang dengan adat budaya Bali yang identik dengan sistem kekerabatan patrilineal. Kami mengatakan bahwa hal tersebut bertolak belakang dengan budaya patriarki yang mewarnai adat budaya Bali, karena Bali identik dengan sistem kekerabatan patrilineal. Sistem ini dijelaskan oleh Punia and Nugroho (2020) sebagai sistem yang hubungan kekerabatannya diperhitungkan melalui garis keturunan ayah dan laki-laki, serta mempunyai kedudukan yang tinggi dalam kehidupan masyarakat. Sejak kecil, perempuan Bali sudah dibentuk dan dipersiapkan untuk menjadi keluarga milik orang lain. Sistem kekerabatan patrilineal yang ditaati di Bali menjadikan laki-laki sebagai tolak ukur garis keturunan, sehingga laki-laki berperan lebih dominan dalam segala aspek kehidupan di Bali dibandingkan perempuan. Luh Ayu dan Manik Mas digambarkan sebagai tokoh superhero perempuan yang memperjuangkan hak-haknya untuk melawan sistem budaya masyarakat Bali yang tunduk pada nilai-nilai budaya patriarkis, namun tidak terlepas dari akar budaya Bali dan agama Hindu. Perlawanannya itu ditunjukkan melalui kekuatan superhero yang dimiliki, kebebasan untuk bertindak dan berpikir, serta keberlangsungan hidup yang tergambar dalam komik.

Clara Listya Dewi sebagai Direktur Komunikasi Tim Basabali Wiki menjelaskan bahwa pemilihan usia 14 tahun sebagai usia untuk superhero perempuan Bali didasari atas pertimbangan karakter. Pada usia tersebut, remaja memasuki masa pembentukan karakter sehingga mudah untuk dibentuk melalui informasi-informasi yang didapatkannya. Selain itu, pemilihan usia 14 tahun juga merepresentasikan remaja yang peduli akan isu lingkungan, literasi, dan isu sosial. 
Seperti yang kami jelaskan pada bab pendahuluan bahwa kekuatan yang dimiliki Manik Mas sangat beragam dalam setiap edisi komiknya. Pada komik edisi pertama dan kedua, kekuatannya ditampilkan seperti sebuah deru angin, pukulan tangan, dan tendangan kaki. Angin dalam sistem budaya tradisional Bali merupakan salah satu dari lima elemen yang membentuk alam semesta (Panca Mahabhuta). Lima elemen tersebut adalah tanah (bumi: pertiwi), air (Apah), api (Teja), angin (udara: Bayu), dan ruang (Akasa). Tubuh manusia diartikan sebagai wujud yang membutuhkan elemen udara ini untuk beraktivitas dan menjalankan proses metabolisme. Berkaitan dengan elemen angin, kekuatan deru angin yang dimiliki Manik Mas merupakan manifestasi dari istilah panca mahabhuta sebagai pedoman dasar dalam penyusunan alam semesta (bhuana agung) oleh manusia (bhuana alit). Hal ini juga berkaitan dengan penjagaan alam seperti yang dijelaskan dalam konsep Tri Hita Karana.

Pada edisi ketiga, kekuatan Manik Mas ditampilkan berupa deru air kuat yang berasal dari gelang tiga warna di tangannya yang berubah menjadi tongkat kecil. Gelang tiga warna digunakan Luh Ayu dan Manik Mas sebagai aksesoris di kedua pergelangannya. Gelang tersebut terbuat dari tiga benang berwarna merah, hitam, dan putih atau disebut dengan gelang $T r i$ Datu. Seperti yang sudah dijelaskan pada pendahuluan bahwa Tri Datu diartikan sebagai susunan benang dengan nilai filosofis yang diyakini oleh umat Hindu memiliki kekuatan. Tri Datu memiliki arti benang (datu) berwarna tiga. Benang Tri Datu bukanlah sesuatu yang asing bagi masyarakat Hindu di Bali. Selain diperuntukkan sebagai pelengkap upacaraupacara tertentu, benang Tri Datu banyak digunakan sebagai identitas diri seseorang.

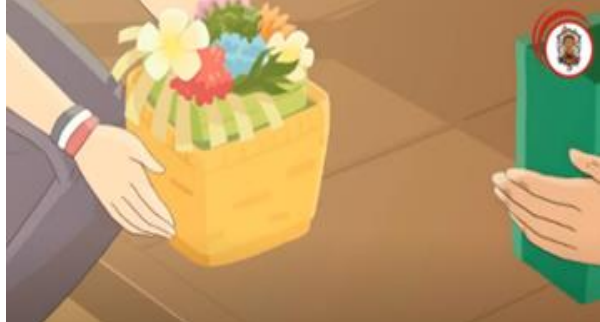

Gambar 3. Wujud Gelang Tri Datu

Sumber: https://dictionary.basabali.org/

Merthawan (2017) menjelaskan dalam penelitiannya bahwa ketiga warna dalam benang Tri Datu melambangkan konsep Ajaran Tri Murti sebagai lambang kesucian. Warna merah melambangkan Dewa Brahma (pencipta), warna hitam melambangkan Dewa Wisnu (pemelihara) dan warna putih melambangkan Dewa Siwa (pelebur) sebagai manifestasi Ida Sang Hyang Widhi Wasa (sebutan bagi Tuhan yang Maha Esa dalam agama Hindu Dharma pada masyarakat Bali). Penggunaan gelang Tri Datu ini merupakan penanda identitas diri Luh Ayu dan Manik Mas sebagai perempuan Bali yang berpedoman pada prinsip hidup Tri Datu sebagai sumber kekuatan dalam hidup untuk mendapatkan perlindungan dari para dewa.

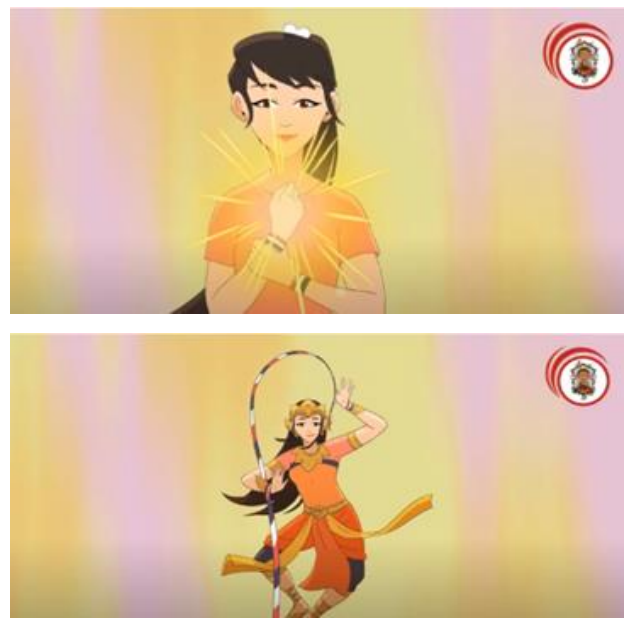

Gambar 4. Proses Transformasi Superhero Manik Mas

Sumber: https://dictionary.basabali.org/ 
Dalam proses transformasi Luh $A y u$, ia memanfaatkan gelang Tri Datu ini sebagai media untuk bertransformasi. Sebuah tongkat kecil mulai terlihat ketika Luh Ayu melakukan transformasi menjadi Manik Mas dengan memanfaatkan gelang tiga warna di tangannya. Tongkat tersebut mampu mengeluarkan deru air kuat yang kemudian dimanfaatkan Manik Mas sebagai superhero perempuan Bali untuk melawan musuh. Musuh Manik Mas yang ditampilkan dalam komik ini merupakan monster berukuran besar dengan taring tajam, wajah menyeramkan, dan bersumber dari tempat-tempat yang banyak dijadikan tempat sampah dan barangbarang yang jarang digunakan lagi bagi manusia. Pada komik edisi kedua monster muncul dari rak buku, sedangkan pada edisi keempat monster muncul dari tengah laut. Di bawah ini terdapat beberapa panel yang menunjukkan Manik Mas sedang melawan musuh menggunakan kekuatan superheronya.
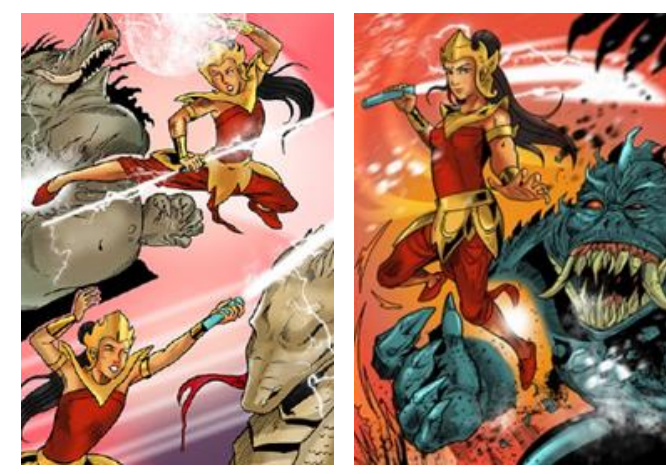

Gambar 5. Kekuatan Deru Air Superhero Manik Mas pada komik edisi ketiga.

Sumber: https://dictionary.basabali.org/

Teologi Hindu Bali memandang air sebagai hal yang istimewa. Air merupakan anugerah pertama dan utama dalam pandangan agama Hindu. Air mendapat tempat dan penghormatan istimewa dalam kehidupan umat Hindu di Bali. Dewa Wisnu merupakan salah satu Dewa Tri Murti yang menggunakan air sebagai simbol, selain api sebagai simbol Dewa Brahma dan angin sebagai simbol Dewa
Siwa (Utama, 2009). Penggunaan air sebagai sumber kekuatan superhero Manik Mas merepresentasikan Manik Mas sebagai superhero perempuan Bali yang mengagungkan dan memuliakan air sebagai sumber kekuatannya. Tidak ada satupun dari ritual keagamaan dalam agama Hindu di Bali yang tidak melibatkan air dalam pelaksanaannya. Bahkan air secara spesifik juga digambarkan sebagai kekuatan Luh Ayu Manik Mas pada komik edisi ketiga. Dengan demikian, agama Hindu seringkali disebut dengan Agama Tirtha atau Agama air (Anadhi, 2016).

Perspektif masyarakat Bali yakin bahwa memelihara siklus air berarti menjaga kemakmuran kehidupan, memelihara kedamaian hati, dan ketenteraman pikiran, sehingga air disebut tirtha panglukatan (air sebagai pembersihan), dan tirtha amrta sanjiwani (air sebagai sumber kemakmuran). Masyarakat Bali sangat menghormati keberadaan air karena dipercaya sebagai wujud dari Dewa Wisnu. Kekuatan deru air yang dimiliki superhero perempuan Manik Mas sebagai kekuatan utama merupakan bentuk upaya pemeliharaan kemakmuran kehidupan, kedamaian hati, dan ketentraman pikiran. Kemakmuran kehidupan di sini merujuk pada kehidupan masyarakat Bali yang bersih, mentaati segala peraturan yang berlaku, dan tidak berperilaku sembarang terhadap lingkungan. Sedangkan kedamaian hati dan ketentraman pikiran yang ditujukan dalam kekuatan air Manik Mas merujuk pada rasa tenang sebagai hasil yang dirasakan oleh manusia dan makhluk hidup lainnya ketika lingkungan alam terjaga dengan baik. Hal-hal tersebut dilakukan karena masyarakat Bali menganggap kemuliaan tertinggi dalam kehidupan adalah hidup selaras damai dengan alam (Utama, 2009). 


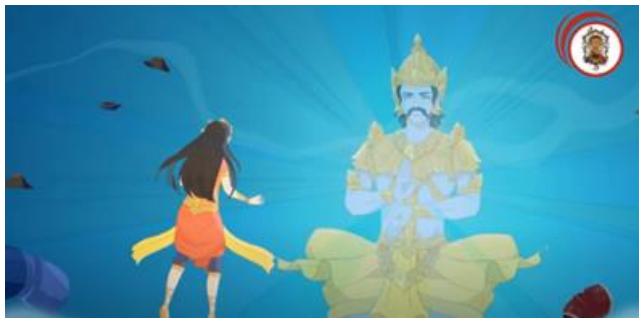

Gambar 6. Manik Mas Bertemu dengan Dewa Wisnu di Dasar Laut

Sumber: https://dictionary.basabali.org/

Dalam komik edisi keempat, terdapat satu panel yang menceritakan Manik Mas tenggelam ke dalam laut dan bertemu dengan seseorang dengan wujud manusia besar di dalamnya. Saat itu, Manik Mas berhasil dikalahkan oleh monster besar yang muncul dari laut dan menenggelamkannya. Namun, setelah ia bertemu dengan seseorang yang berada di dalam laut ia diberikan sebuah berlian yang berkilau, kemudian seketika mendapatkan kekuatannya kembali dan berhasil mengalahkan monster. Wujud manusia besar yang ditemui Manik Mas di dalam laut kami asumsikan sebagai Dewa Wisnu yang merupakan salah satu Tri Murti dalam ajaran agama Hindu. Kami mengasumsikan demikian mengingat bahwa air merupakan simbol utama dari Dewa Wisnu. Meskipun kekuatan yang dimiliki Manik Mas melebihi kekuatan manusia pada umumnya, ia tetap memiliki kelemahan sehingga mampu dikalahkan oleh monster laut. Manik Mas dalam komik ini ditampilkan sebagai superhero perempuan Bali yang memiliki kekuatan super untuk melawan sesuatu yang tampak, namun hidup, dan matinya tetap berada dalam lindungan dewa-dewa.

Pada edisi keempat, kekuatannya adalah berupa cambuk tiga warna yang digunakan Manik Mas untuk melawan monster laut. Cambuk juga ditampilkan secara visual dengan tiga warna yang serupa dengan warna gelang Tri Datu yang digunakan Luh Ayu dan Manik Mas. Dengan demikian disimpulkan bahwa Manik Mas memiliki kekuatan deru angin kuat, deru air kuat, cambuk tiga warna, pukulan tangan, dan tendangan kaki. Jenis kekuatan angin, air, dan cambuk tiga warna memanifestasikan prinsip hidup masyarakat Bali yang bertumpu pada Tri Hita Karana dan Tri Datu. Hal ini menunjukkan bahwa seluruh kekuatan Manik Mas merupakan hal-hal yang berkaitan ajaran agama Hindu di Bali.

Identitas pahlawan super biasanya terkandung dalam kostum ikonik, yang mampu mengekspresikan biografi, karakter, serta kekuatan yang dimilikinya. Melalui kostum yang digunakan, identitas superhero tersebut disembunyikan oleh tokoh superhero. Kostum yang digunakan Manik Mas dalam identitasnya sebagai superhero merupakan kostum yang memiliki unsur-unsur identitas Bali. Di bawah ini terdapat potongan beberapa gambar dari keempat edisi komik Luh Ayu Manik Mas.

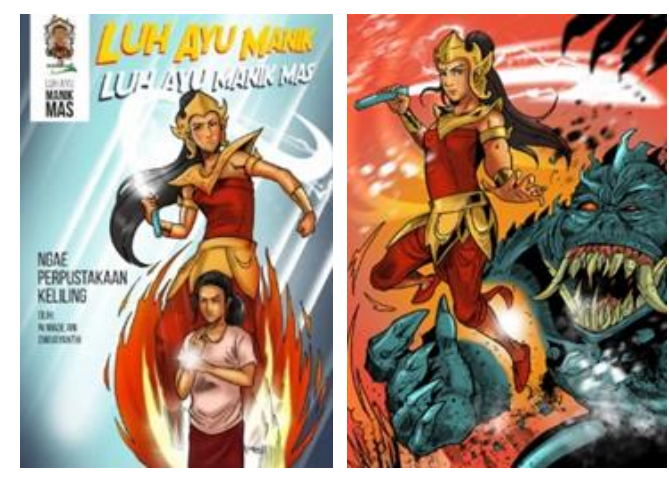

Gambar 7. Busana Superhero Manik Mas Sumber: https://dictionary.basabali.org/

Gambar pertama menampilkan dua wujud Luh Ayu dan Manik Mas dalam dua identitasnya, yaitu wujud perempuan biasa dan wujud superhero perempuan. Gambar kedua menampilkan Manik Mas bersama musuhnya yang ditampilkan dalam wujud monster berwarna biru dengan taring yang besar. Ketika Luh Ayu bertransformasi menjadi superhero, ia dibalut dengan busana khusus dan aksesoris lainnya yang didominasi oleh warna merah dan emas. Secara umum, kostum ini serupa dengan kostum Sri Asih yang mengandung estetika lokal, namun detailnya berbeda. 
Kostum tersebut terdiri dari mahkota emas, hiasan bahu, gelang emas, gelang tiga warna, gelang emas pada lengan, selendang (senteng), hiasan emas pada pinggang, dan kain kamen khas Bali berwarna merah. Jenis pakaian dan hiasan yang digunakan Manik Mas merupakan rangkaian dari busana adat Bali yang banyak digunakan oleh masyarakat Bali sebagai pakaian dalam acara keagamaan. Seperti yang dijelaskan dalam peraturan gubernur Bali nomor 79 tahun 2018 tentang hari penggunaan busana adat Bali: busana Bali digunakan sebagai wujud pelindungan budaya yang mencerminkan sifat kesantunan, keteduhan, kedamaian, dan kebanggaan bagi pemakainya. Manik Mas menggunakan pakaian adat Bali sebagai bentuk perlindungan budaya dan penanda identitas perempuan Bali bagi dirinya.

Jika dibandingkan dengan superhero perempuan lainnya, Manik Mas merupakan superhero yang tidak tunggal (sendirian) dalam menjalankan misi, karena selalu merangkul teman-temannya untuk menyelesaikannya (Priyatna, 2020). Manik Mas memperjuangkan keharmonisan lingkungan Bali dengan menjaga bumi (palemahan) melalui tindakan-tindakan, pemikiran, dan perkataan yang baik dan suci. Tindakan-tindakan tersebut bersandar pada konsep ajaran agama Hindu, Tri Hita Karana. Selain lingkungan, tokoh superhero Luh Ayu dan Manik Mas juga memperjuangkan kesetaraaan gender melalui hal-hal yang tersirat dalam cerita komik. Kesetaraan gender yang dimaksud merupakan pemberontakan terhadap marjinalisasi perempuan dalam dunia superhero dan adat budaya Bali. Manik Mas hadir sebagai superhero perempuan lokal di tengah minimnya karakter perempuan dalam dunia superhero, terutama Indonesia. Manik Mas juga hadir sebagai perempuan Bali yang dimuliakan oleh ajaran agama Hindu (agama dominan di Bali), di tengah budaya patriarkis yang masih sangat kental di Bali.

\section{PENUTUP}

Dari hasil analisis atas empat edisi komik Luh Ayu Manik Mas diperoleh beberapa atribusi yang menunjukkan bagaimana $L u h$ Ayu Manik Mas merepresentasikan superhero perempuan Bali. Luh Ayu Manik Mas direpresentasikan sebagai superhero perempuan Bali yang dimuliakan oleh agama Hindu melalui kekuatannya. Kekuatan tersebut menunjukkan bentukbentuk perlawanan terhadap budaya patriarkis di Bali.

Sebagai tokoh superhero perempuan beridentitas Bali, Manik Mas memanifestasi identitas lokal yang ditampilkan melalui kekuatan Manik Mas sebagai superhero. Kekuatan tersebut merupakan deru angina dan deru air kuat yang keluar dari gelang Tri Datu yang ia gunakan di pergelangan tangannya. Gelang Tri Datu yang digunakan Luh Ayu dan Manik Mas sebagai sumber senjata angin dan air merepresentasikan perempuan Bali yang berpedoman pada prinsip hidup Tri Datu sebagai sumber kekuatan. Selain dua kekuatannya, Manik Mas juga melawan musuhnya menggunakan cambuk tiga warna yang juga merupakan manifestasi dari prinsip hidup Tri Datu sebagai sumber kekuatannya.

Beberapa kegiatan yang dilakukan Luh Ayu dan Manik Mas dalam komik ini merepresentasikan dirinya sebagai superhero perempuan Bali yang menyandarkan seluruh kehidupan pada konsep Tri Hita Karana. Prinsip hidup ini dijadikan landasan bagi Luh Ayu dan Manik Mas untuk melakukan kegiatan di kehidupan sehari-hari. Hal tersebut dilakukan untuk mewujudkan keharmonisan hubungan antara manusiaTuhan (parhyangan), manusia-manusia (pawongan), dan manusia-lingkungan alam (palemahan). Melalui gambaran-gambaran di atas, Luh Ayu dan Manik Mas menunjukkan bahwa dirinya merupakan superhero perempuan yang memperjuangkan lingkungan Bali dari kejahatan, juga memperjuangkan 
kesetaraan gender dalam dunia superhero dan adat budaya Bali.

\section{DAFTAR SUMBER}

Anadhi, I. M. G. (2016). Wisata Melukat : Perspektif Air pada Era Kontemporer. Jurnal Studi Kultural, 1(2), 105 - 109.

BASAbali. (2020). Cerita Perjalanan Luh Ayu Manik Mas Pahlawan Putri Bali. https://dictionary.basabali.org/.

Candrawan, I. B. G. (2015). Kosmologis Masyarakat Hindu di Kawasan Tri Danu Dalam Pelestarian Lingkungan. Junral Dharmasmrti, 13(26), 1 - 135.

Coogan, P. (2018). Wonder Woman : Superheroine, Not Superhero. Journal of Graphic Novels and Comics.

Dwijayanthi, N. M. A. (2019). Komik Luh Ayu Manik Mas: Ngae Perpustakaan Keliling. Balil: Yayasan BASAbali Wiki.

Hall, S. (1997). Representation : Cultural Representation and Signifying Practices. London SAGE Publication.

Hasian, I., \& Mardika, A. S. (2017). Pengaruh Komik Asing Terhadap Visualisasi Perkembangan Komik di Indonesia. Jurnal Magenta, 1(1).

Indonesia, R. (2018). Peraturan Gubernur Bali Nomor 79 Tahun 2018 Tentang Hari Penggunaan Busana Adat Bali.

Kiriana, I. N. (2017). Kewajiban dan Hak Wanita Hindu Dalam Keluarga dan Masyarakat. Jurnal Kajian Gender \& Anak, 12(2).

Kurniawan, R. A. (2019). Kemunculan Komik Adipahlawan Indonesia dan Faktor yang Mempengaruhinya. Art \& Culture Journal, 2(1).

Merthawan, G. (2017). Pemahaman Penggunaan Benang Tri Datu Pada Remaja Hindu di Kota Palu. Jurnal Ilmiah Pendidikan, Agama dan Kebudayaan Hindu, 8(2), 11 - 17.

Palmer, E. (2004). Supeheroes and Gender Roles, 1961-2004. Entertainment Studies Interest Group.

Prabowo, W. (2012). Representasi Identitas Lokal Sebagai Sebuah Subculture : Analisi Kritis Pada Komik Garudayana. (Sarjana ), Universitas Indonesia, Depok.
Pratiwi, S. S. (2013). Women's Portrayal in the Comic Books: A Visual Grammar of the Heroines' Portrayals in the Selected Comic Books Published by DC Comics and Marvel. (Sarjana), Universitas Pendidikan Indonesia, Bandung.

Priyatna, A. (2020). Indonesian Female Superheoes: Forginh the Feminine in the Masculine World.

Punia, I. N., \& Nugroho, W. B. (2020). Bali Diaspora di Daerah Transmigrasi : Representasi Kearifan Lokal Bali di Kabupaten Bolaang Mongondow, Sulawesi Utara. Journal of Bali Studies, 10 (1).

Rahmawati, N. N. (2016). Perempuan Bali dalam Pergulatan Gender (Kajian Budaya, Tradisi, dan Agama Hindu). Jurnal Studi Kultural, 1(1), 58 - 64.

Ridho, L. F. (2014). Memahami Indentitas Hibrida pada Komik Indonesia Kontemporer. Jurnal Ilmu Komunikasi, 2 (2).

Robb, B. J. (2014). A Brief History of Superheroes. Philadelphia Running Press Book Publishers.

Salsabil, R. (2019). Superhero Perempuan dalam Komik di Indonesia (Kajian Feminis - Marxis). Jurnal Perpustakaan ISI Yogyakarta.

Sobur, A. (2001). Analisis Teks Media. Bandung: PT. Remaja Rosdakarya Offset.

Suarnada, G. M., \& Ritawati, N. N. (2017). Persepsi Remaja Hindu Terhadap Perayaan Hari Raya Siwaratri di Kota Palu. Jurnal Ilmiah Pendidikan, Agama dan Kebudayaan Hindu, 8(2), 1 -10.

Suwena, I. W. (2017). Fungsi dan Makna Ritual Nyepi di Bali. Universitas Udayana, Denpasar.

Temaja, I. G. B. W. (2017). Sistem Penamaan Orang Bali. Jurnal Humanika, 24(2), 60 72

Utama, I. W. B. (2009). Air Pada Era Kontemporer: Sekularisasi Alam Batin Orang Bali. Paper presented at the 3rd South and Southest Association for the Study of Culture and Religion (SSEASR), Denpasar, Bali. 